\title{
Prof. Hasan Pekmezci’nin Eğitimci Kişiliği, Sanatı ve Hayatı Üzerine
}

Doç. Deniz Onur Erman

\section{Özet}

Hasan Pekmezci; eğitimin bir insanın hayatını nasıl kökünden değiştirebileceğini kendi deneyimlemiş biri olarak eğitime tüm kalbiyle inanan ve öğrencilerini ilk günden beri ona emanet edilen kutsal değerler olarak gören bir eğitimcidir. Nitekim meslek hayatı boyunca da sayısız öğrenciye ışık tutmuş, verdiği her derste gerek uygulama, gerek kuramsal açıdan öğrencilerinin ufkunu genişletmiştir. Diğer taraftan Pekmezci, Çağdas Türk Sanati’nın yetiștirmis olduğu çok üretken bir sanatçıdır. Hayatının bir iz düşümü gibi olan resimlerindeki her leke, her renk, her figür gerçek, açık, dürüst ve yaşanmıştır. Onun eserlerinde sanatçının gerçeklerine zıt ve uyumsuz tek bir nokta bulunmaz. Sanatçının etkilendiği her şey apaçık esere dönüşmüş̧ür. Eserlerindeki samimiyet gerçekliğinden ve yaşanmış/ı̆̆ından gelmektedir. Tıpkı Plekhanov'un sözündeki gibi; "iç̧eriği olmayan resim ruhsuz, bir ceset gibidir".

Anahtar Kelimeler: Hasan Pekmezci, Çağdaş Türk Resmi, Özgün Baskı, Kuş Figürü.

\section{ON HASAN PEKMEZCI'S EDUCATOR PERSONALITY, ART AND LIFE}

\section{Abstract}

As someone who has personally experienced how education can dramatically change a person's life, Hasan Pekmezci ise a whole-hearted educator who, from the first day, treats students as sacred valuables trusted to him. Accordingly, he has guided countless students throughout his professional life and has introduced them, both practically and theoretically, to new horizons in each and every lesson he has given. On the other hand, Pekmezci is one of the most productive artists of Contemporary Turkish Art. Every spot, color, and figure in his paintings are real, bare, sincere and alive. His works do not include even a single argument that is contrasting to or conflicting with the artist's reality. Everything that has impressed the artist has been transformed explicitly into his work. The sincerity of his work arises from authenticity and life experiences. As Plekhanov once said, "A painting without content is like a corpse with no soul."

Keywords: Hasan Pekmezci, Contemporary Turkish Painting, Printing, Bird Figure. 


\section{Giriş}

Güzel sanatlar fakültesinde bir sanat öğrencisi için hangi bölümde olursa olsun atölyeler sadece bir derslik ya da bir eğitim alanı değildir. Atölye çok daha fazla anlam taşır. Tüm sanat öğrencileri bunu bilir. Sanat öğrencisinin evi gibi olur atölye. İçinde günlerini gecelerini, saatlerini, duygu yoğunluklarını, paylaşımlarını, aşklarını, öfkelerini bazen göz yaşlarını yaşadığı, ürettiği, tükettiği bir yuva olur. Gencecik öğrenci o atölyede büyür, olgunlaşır. Yeri gelir evinden çok vakit geçirir o atölyede. Duvarlarının her karışını, gıcırdayan kapısını, bozuk penceresini, ışığı titreyen florasan lambasını kendi odasından bile daha iyi tanır. Öğrenci atölyede aidiyet duyabilmelidir. Ait hissederse üretimi artar, motivasyonu artar. Kendi köşesinde bir yaşam alanı kurar ve orada üretir. Atölyenin tozu, kiri, damlatan musluğu bile özlenir uzak kalındığında. Çünkü orası ürettiğin, öğrendiğin, paylaştığın özel bir mekandır. Bazı hocalar için atölye, ders saatinde dersini verdiği, ama yaşamadığı bir eğitim alanıdır yalnızca, ama Hasan Pekmezci bulunduğu her yeri bir atölyeye dönüştüren, her atölyeyi de sıcacık bir yuvaya çeviren, öğrencisi için bitmez tükenmez bir kaynak, ender karşılaşılan hocalardandır.

Hasan Pekmezci Hoca'nın elleri hep boyalıdır, o hep atölyede ve hep ayaktadır. Yüzü güler, sesi sıcak ve yumuşaktır. Eleştirileri yapıcıdır. Öğrencisini ezmez, onu üst basamaklara taşır. Etrafı öğrencilerle çevrilidir. $\mathrm{O}$ atmosfere girdiğiniz anda çalışmadan duramazsınız. Atölye sizi içine çeker ve hemen ait hissedersiniz kendinizi. Sanki yıllardır oradaymışsınız gibi, herkesi tanıyormuşsunuz ve onlarda sizi tanıyorlarmış gibi. Her sorunuza cevap bulabilirsiniz. Hasan Hoca'nın atölyesinde öğrenciler yalana, bahanelere, numaralara sığınmazlar, bilirler ki dürüstçe ve açıkça söyledikleri her söz dinlenir ve ciddiye alınır. Yemek yemez, oturmaz, dinlenmez. Çalışmayla beslenir. Onu dinlendiren şey üretmektir. Onu öyle görünce siz de yorulmaktan utanırsınız. Hasan Hoca, öğrenciden korkmaz, çekinmez. Öğrencisinin önünde çalışır. Bir sanat öğrencisi için hocasının çalışma ve üretme sürecine tanık olmak eğitimin en büyüğüdür. Öğrenci üreten ve çalışan hocayı ciddiye alır, ona inanır ve güvenir. Ünvanlar, egolar, titrler ve kibir yoktur onun atölyesinde. Üretmek, çalışmak ve paylaşmak vardır. Her malzemesini paylaşır, her bilgisini son damlasına kadar verir, siz yeter ki isteyin. "Bu da bana kalsın" demez. "Sen kimsin?" diye sormaz "Ne öğrenmek istiyorsun? Hadi başlayalım" der ve sen, o atölyenin büyüsüne kapılıp içeriye süzülürsün. "Kim olursan ol gel, öğrenmek istiyorsan gel" mottosu ile yılların birikimini paylaşmaktan coşku duyar Hasan Pekmezci Hoca. Hasan Hoca'nın fakültedeki odasının kilidi yoktur. Kapısı herkese açıktır. Öğrenmek isteyene, araştırmak isteyene, sormak isteyene sonuna kadar açıktır. Kitapları, katalogları, arşivleri saklamaz kendine. Şiirlerle şiir tadında ders anlatır. Salt kitap bilgisiyle ürkütmez öğrencisini, yaşanmış örneklerle yaşatarak anlatır. Sorgulatır, düşündürür, yorum yaptırır. Tam da sanatın nasıl anlatılması gerektiği gibi. Hasan Hoca cep telefonu kullanmaz ama ona ulaşmakta hiç zorluk çekmezsiniz. Bir öğrencisinden e-posta aldığında hiç vakit kaybetmeden gece saat kaç olursa olsun dönüş yapar. "Öğrenci hocasını arıyorsa, e-posta atıyorsa ihtiyacı var demektir, bekletmemek gerek" der.

Bir sanat öğrencisinin en temel ihtiyaçlarından biri de kitap bilgisini gerçeği ile örtüştürebilmektir. Öğrenci senelerce kitaplarda gördüğü, derslerde öğrendiği, üzerine projeler hazırladığı sanat akımlarını, dünya müzelerini, büyük sanatçıları ve eserleri gözleriyle görmeden, bizzat yaşamadan ve deneyimlemeden özümseyememektedir. Tecrübe ile hayata aktarılamayan, havada kalan her bilgi unutulmaya mahkumdur. Hasan Hoca, sanat öğrencileri için kitap sayfalarındaki bilgilerin gerçek hayatla entegrasyonunu sağlama konusunda da ileri görüşlülüğü ile öncü bir akademisyen olmuştur. Hacettepe Üniversitesi'nde görev yaptığı dönemlerde başlattığı "Öğrenci Sanat Gezileri" ile yüzlerce sanatöğrencisi sanat tarihini Louvre Müzesi'nde, Rembrant'ın sanatını Amsterdam'da sanatçının atölyesinde görerek, Empresyonist ressamları Paris'te Montmartre sokaklarında dolaşarak ve yaşayarak öğrenme imkanı bulmuşlardır. 18 yaşında gencecik bir sanat öğrencisi için Van Gogh'u kitaplardan çıkaran, Renoir'ın tablolarındaki ışığı bizzat yaşatan, Pompidou'da Çağdaş Sanat'ın en yetkin örneklerini deneyimlemeyi sağlayan Hasan Hoca'nın bu sanat gezilerinin değeri paha biçilemezdir. Öğrenciler için uzakları yakınlaştıran, hayalleri elle tutulur hale getiren bu yoğun sanat gezileri büyük bir motivasyon kaynağı olmaktadır.

Hasan Pekmezci, eğitimin bir insanın hayatını nasıl kökünden değiştirebileceğini şahsen deneyimlemiş biri olarak eğitime tüm kalbiyle inanır ve tüm yatırımını eğitim üzerine yapar. 1945 Beyşehir-Üzümlü doğumlu olan Pekmezci köyde pek de kolay geçmediğini anlattığı hüzün dolu çocukluk yıllarında onu hayata sıkı sıkı bağlayan şeyin yine eğitim olduğunu her fırsatta vurgulamaktadır. Karşısına çıkan iyi öğretmenler Pekmezci'nin yeteneğini farkedip onu desteklemişler ve eğitim gördüğü okullar onu büyük bir donanımla hayata hazırlamışlardır. Pekmezci ilk resme yönelişini şu sözlerle anlatmakta. "ilk resim dersinde öğretmenimizin bir "Aslan ooolum" sözü ile resme yöneldim. Bundan sonra her günüm resimle doldu. Bir süre sonra sınıfta adım "resimci çocuk" oldu. O gün öğretmenimiz "Böyle resim mi olur?" diye enseme bir şaplak indirseydi ne olurdu? Zaten alıngan-kırılgan bir çocuk olarak ben yoktum. 'Bir sözün abad; bir sözün berbat ettiğinin', edebileceğinin somut bir örneğidir bu". 
Pekmezci, 1958 senesinde İvriz Öğretmen Okulu'nu kazanır. Yaşam öyküsünün tamamen iyi okullar, başarılı eğitimciler sayesinde anlam kazandığından övgüyle bahseder. "Hepsi özverili, hepsi öğrenci ve okul odaklı, hepsi çağdaş, Cumhuriyetçi, Atatürkçü. Hepsi alanında idol. Her zaman minnetle andığım. Bizi biz yapan aydın insan kuşağı. Öğrenciyi varoluş nedeni sayan. Bizim yaşamımız boyunca temel ilkemiz bu insanlara layık-yaraşır eğitimci olabilmemiz." Henüz bir ilkokul öğrencisiyken öğretmeninden kıymet ve destek gören bir çocuğun eğitim basamaklarını tırmanırken eğitime gönül vermesi ve hayatının yönünü bu şekilde belirlemesi işte böyle başlamaştır. 1962'de İvriz Öğretmen Okulu'nun Orta kısmında başta Mehmet Karaman olmak üzere, İsa Başlıŏ̆lu ve Namık Sevinç Arkun gibi nitelikli resim öğretmenlerinin yönlendirmeleri ile resim sevgisi daha da gelişir. Bu alana olan yoğun ilgisi nedeniyle sınavla İstanbul Çapa Öğretmen Okulu Resim Seminerleri'ne gönderilir ve bu eğitimleri birincilikle tamamlar. 1965 senesinde Gazi Eğitim Enstitüsü Resim Bölümü'nü kazanması Pekmezci için eğitiminin en önemli basamaklarından biri olur. Üniversitede Adnan Turani, Turan Erol, Nevide Gökaydin, Hidayet Telli, Kayıhan Keskinok, Mürşide İçmeli, Muammer Bakır, Hamza İnanç, Nevzat Akoral, Mustafa Tömekçe gibi yetkin sanatçı-eğitimci kadrosundan çok seyler ögrenerek ve özellikle sanatın günübirlik eğlence işi olmadığını, sanatın insan yaşamını saran sarmalayan en üst düzeyde insanî etkinlik olduğunu özümleyerek mezun olur. Öğretmenliğin önemine ve gerçek anlamda kutsallığına inanarak meslek hayatına başlar. Illk görev yeri olan Arifiye Öğretmen Okulu'nda öğretmen ve yönetici olarak özveri ile yedi yıl çalışır. Daha sonra Çankırı Merkez Ortaokulu'nda üç yıl öğretmenlik yapar. (http://www.hasanpekmezci.com/biyografi) Pekmezci'nin hayatında resim hep koruyucu kalkan olmuştur, bunun bilincinde olan eğitimciler ve eğitim sistemi sayesinde.

Bir ülkenin eğitim politikasının her bireye eşitlik sağlayan bir eğitimde eşitlik sistemi üzerine temellendirilmesi, imkansızlıklar içinde yaşayan bir köy çocuğu ile geniş imkanlar içinde yetişen kentteki çocuğu aynı sınıfta, aynı sırada yan yana eşit haklara sahip hale getirebilmektedir. Pekmezci ülkemizde köy enstitülerinin bunu sağlayan en değerli yapılanma olduğunu savunurken, bu değere sahip çıkamamamızın ve uzun ömürlü olamayışının üzüntüsünü de dile getirmektedir.

Hasan Pekmezci yalnız başladığı sanat ve eğitim serüvenine kendisi gibi sanatçı ve eğitimci olan eşi Şükran Pekmezci ile devam eder. İkisi de eğitime gönül vermiş eğitimci olmak için yaratılmışı. Artık bu hayat yolunda tek başına değildir. Aynı dili konuşabildiği, aynı ilkelere ve düşüncelere sahip, her an onu destekleyen bir eşi vardır. "Karım-kocam" demeyi sevmez
Hasan Pekmezci, "Eşim" der. Yıllar önce İskilip'de tanımadıkları yaşlı bir amcadan duydukları bir söz çivi gibi çakılır beyinlerine. Hazine gibi bir sözdür bu; "Insanın eşi nefesidir" demiştir İskilipli yaşlı amca. Pekmezciler birbirlerine duydukları sevgi, saygı ve değeri bu sözle özetlerler biribirlerinin eşi ve nefesi olmayı seçerler. Bu bilgece seçilmiş üç kelime Pekmezci'nin aklııı çok meşgul eder. Konuyla ilgili şunları dile getirir; " 'karı' sözcüğünde bir küçümseme, aşağılama, iteleme görürüm hep. Aynı şekilde 'koca' sözcügünnde de. Amirden, egemen birinden söz eder gibi. "Karım", "Kocam" sözcüğünde de malik olma, mal sahibi olma gibi bir itici anlam bulurum: "Ayakkabım, çantam" der gibi. Ama eş-eşim gibi sözcükleri baş tacı sayarım. Evlilik ve evliliğin getirdiği denklik, dayanışma, birlikte yaşamı paylaşma sözcüklerini birbirlerine eşdeğerlik olarak gördüğümden. Bu arada çok kaba gibi görülse de bir örneği her zaman veririm bir köy çocuğu olarak, gözlemlerimden yola çıkarak: "Eşi denk olmayan dövenden, hamur değil; çamur çıkar." (Görsel: 1,2,3,4)
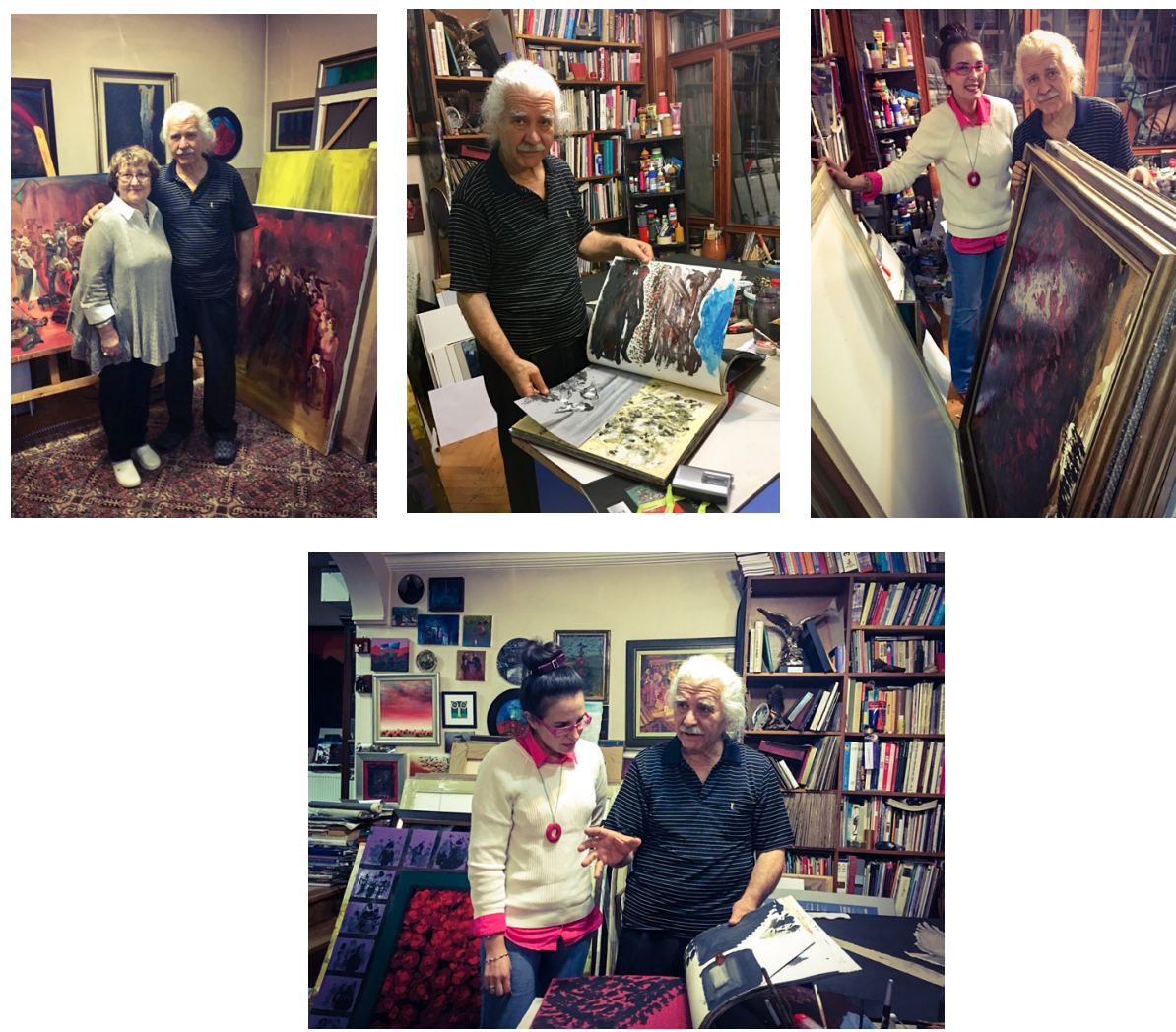

Görsel I,2,3,4. Ankara Batıkent'te ev-atölyelerinde Hasan Pekmezci ve eşi Şükran Pekmezci ile. 
1979 senesi geldiğinde Pekmezci ailesi artık dört kişidir. İki çocuklarıla ele ele vermiş, dayanışma içinde çalışan ve üreten sevgi, saygı dolu bir aile kurmuşlardır. Bu tarihte Hasan Pekmezci yetiştiği ve ideali olan Gazi Eğitim Enstitüsü Resim Bölümü'ne Öğretmenler Kurulu kararı ile, öğretmen olarak davet edilir. Bu kurumda Serigrafi atölyesini kurarak çalışmalarına başlar. Sergiler, atölye çalışmaları, akademik çalışmalar ve ödüller beraberinde gelir. O da hayatı boyunca örnek aldığı ve hayatının bir noktasında elinden tutmuş ona yol göstermiş hocaları gibi kendi öğrencilerine yol gösteren bir üniversite hocasıdır artık. Öğrencilerini evlatlarından, torunlarından ayrı tutmaz Hasan Pekmezci. Her bir öğrencisinin sorumluluğunu kendi çocuğuymuşcasına sahiplenir. Çok hassas bir konudur bu onun için ve şu sözleriyle dile getirir hassasiyetini; "Öğrenci velinimetimizdir bizim. Biz öğrencilerimizi bize emanet edilen kutsal değerler olarak gördük ilk günden beri. Üzerine titrenmesi gereken, asla ihanet, hıyanet edilmemesi gereken gerçek anlamda kutsal değer. Onlara bu ulusun geleceği gözü ile bakmak, "Iş̧te geldik, gidiyoruz"'dan sonrasını emanet edebileceğimiz, onun güçlü, onun başarılı olmasını candan isteyeceğimiz emanet. Şu bir yaşam kuralıdır: Güçlü olmayan, güçlülerin ayakları altında kalmaya, ezilmeye, kul köle olarak kullanılmaya açıktır." İşte bu nedenle öğrencilerini bilgiyle, donanımla besler ve güçlü birer birey olmaları için özenle yetiștirir Hasan Pekmezci için eğitimcilik gerçek bir bayrak yarışıdır, idolden idole taşınan ve çok ciddiye alınması gereken bir değerdir. 1987 senesinde Hacettepe Üniversitesi Güzel Sanatlar Fakültesi Resim Bölümü Öğretim Üyeliğine, Baskı Resim atölyelerini kurmak ve bu alanın derslerini vermek üzere atanır. Yeni bir kurum, yeni bir dönem başlar Hasan Pekmezci için. Bu dönemde eserleri artık Türkiye sınırlarını aşmaya başlar. Uluslararası pek çok sergi, yarışma ve çalıştaylara katılır. Yayımlanmış ders kitapları akademik araştırma ve yayınları, sempozyum katıımları, kongre sunumları, jüri üyelikleri ile oldukça yoğun bir akademik hayatın içinde durmadan üretir. 1987 senesinde Doçent, 1995 senesinde Profesör ünvanlarını alır. Üniversitede görev yaptığı sürede akademik ve sanatsal çalışmalarının yanısıraidari görevler de üstlenmiştir. Önemlikurumlarda sanat danışmanlığı yapmaktadır. ODTÜ Endüstri Ürünleri Tasarımı Bölümü'nde ve Başkent Üniversitesi Güzel Sanatlar Fakültesi'nde de Baskı Resim Atölyelerini kurar ve alan derslerini yürütür. 2012 senesinde Hacettepe Üniversitesi Güze Sanatlar Fakültesi'nden emekli olan Pekmezci, emekliliğinin ardından da bilgi ve birikimleri ile üniversite öğrencilerinin yolunu aydınlatmaya ve onlara ışık olmaya devam etmektektedir. 2012 senesinden günümüze Gazi Üniversitesi Güzel Sanatlar Fakültesi'nde Özgün Baskı Resim Atölyesi'ni kurmuş ve burada dersler vermektedir.

Hasan Pekmezci'nin resimleri onun hayatının bir iz düşümü gibidir. Eserleri de kendisi kadar gerçek, açık ve dürüsttür. Her bir renk, her bir leke, tek tek her bir figür yaşanmış ve iz bırakmıştır. Ezbere değildir. Sanatçının gerçeklerine zıt, uyumsuz tek bir nokta bulamazsınız. Sanatçıyı etkileyen her şey apaçık esere dönüşmüştür. Eserlerindeki samimiyet gerçekliğinden ve yaşanmışlığından gelmektedir. Sanatçının şu sözleri konuyu açıklar niteliktedir; "Duygularım arasında yer bulmayan, zoraki, yapay, biçimsel oyunlar için resim yapmadım bu zamana kadar. Ne yapmışsam hayatıma değen, anısı olan, uyaran, yüreğimi buran, içimi acıtan; yeri geldiğinde ürküten, nefret ettiren ne varsa resimlerini yaptım, yaparım. Dahası şiir olarak, öykü-anı olarak yazarım." (Görsel:5,6,7)
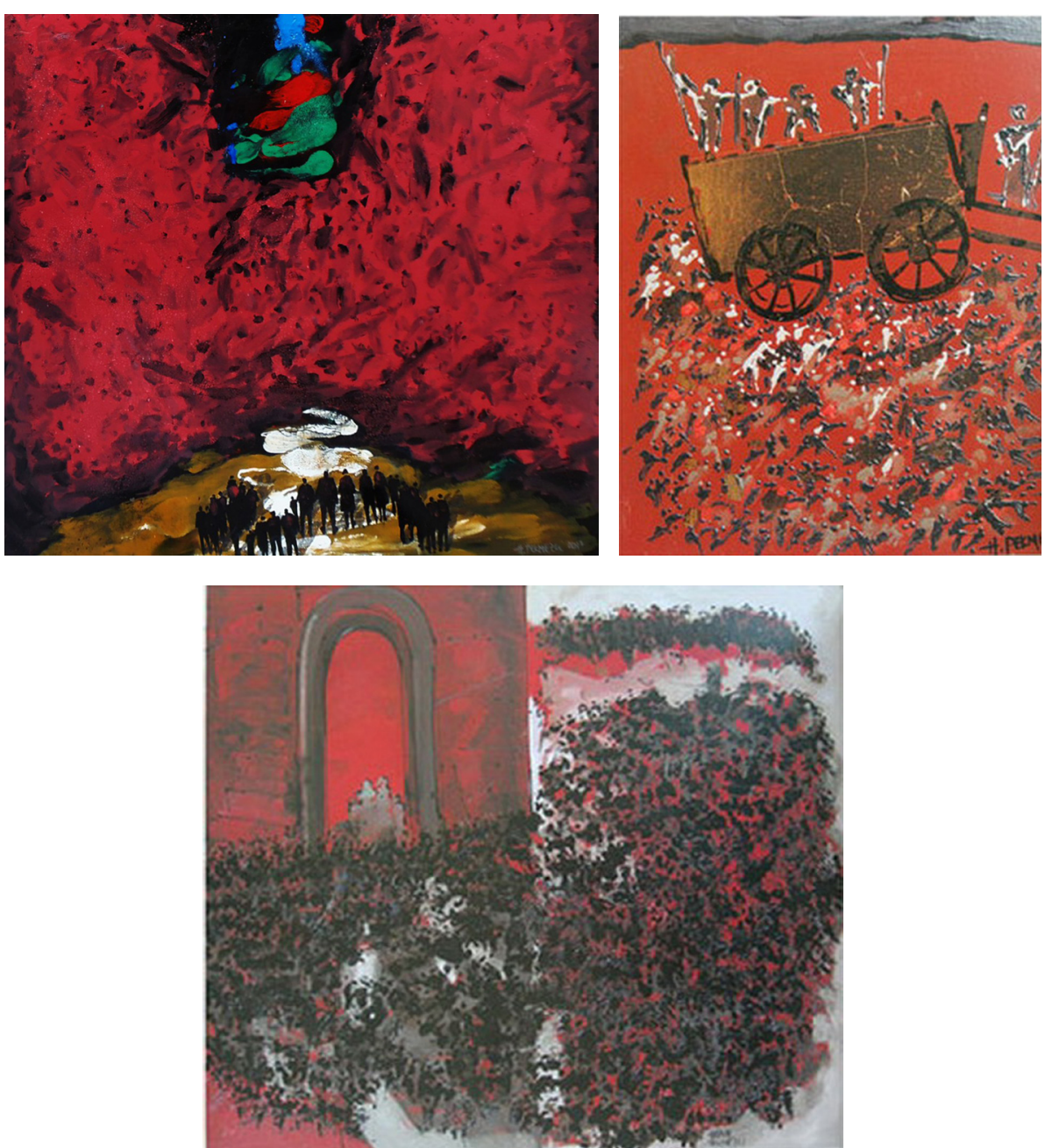

Görsel 5,6,7. Hasan Pekmezci’nin eserlerden örnekler. "Iinsanlarımız" 
Pekmezci resimlerini gruplara ayırmayı, kategorize etmeyi sevmez. "Zaman içerisinde eserlerimi araştıranlar, bu konuda yazı yazanlar olursa yapsınlar ama ben kategorize etmiyorum. Ancak resimlerimde dışavurumcu, sembolist, biraz öykücü özellikler ağır basar." sözleriyle kısaca özetliyor. Pekmezci'ye sanat anlayıșı sorulduğunda; "Sanatın yaşamın izdüşümü olduğuna, yaşamdan beslenmesi gerektiğine içten inanan biriyim. Yaşamın her yönüyle bizim insani duyarlığımız içinde bulunduğuna, bu iklimin, atmosferin bir bitki örtüsünü etkilemesi gibi duyarlığımızı etkilediğine inananlardanım. Dünya görüşüm de bu yöndedir. Kendi yaşamımın bütün evreleri, toplumsal sorunlar, dünya sorunları bizim duygu, düşünce ve eylem haritamızı ve yaşamı anlama, algılama ve sorgulama bilincimizi belirler. Bu nedenle resimlerime aldığım bütün temalar beni etkileyen, yaşamıma dahil olan alanlardan." sözleriyle açıklıyor sanat anlayışııı. Hasan Pekmezci, sanat anlayışında belli kalıplara, kurallara, tarzlara saplanıp kalan ve bunun dısıına çıkarsa eleștirileceğinden korkan bir sanatçı değil. Hayat karşısına ne çıkarırsa onu yaşayan ve etkilendiğini çekinmeden yansıtan bir sanatçı. Belli bir tekniğe, malzemeye, tarza saplanıp kalmıyor ve değişimden korkmuyor. Bugün Türk sanatının en büyük açmazlarından birinin de bu korku olduğunu eleştiriyor. "Sanat insanlarının 'bu benim tarzım, bundan baška bir șey yaparsam eleștirilirim" çekincesi bir saplantıdır. Şöyle düşünelim; bundan otuz yıl önce, yirmi yıl önce ben Hasan Pekmezci olarak aynı anatomik, duygusal, düşünsel yapı içinde miydim? Bırakın beni içinde yaşadığımız toplum otuz yıl, yirmi yıl önceki toplum mu? Otuz yıl önceki portremi ben tanıyamıyorum ki. Değişim kaçınılmazdır; duygusal, düşünsel, eylemsel. Öyleyse niye otuz yıl önce yaptı̆̆ım resmi yapayım ki? Bunca duygusal, düşünsel, biyolojik, toplumsal değişim yaşanırken tarz, ekol, teknik saplantısına gireyim ki!" sözleri ile konuya açıklık getiriyor.

Hasan Pekmezci'nin resimlerinde kendi geçmiş yaşantıları, anıları ve izlenimleri kadar toplumun içinde bulunduğu durum ve toplumsal gerçekler de tüm gerçekliği ile mevcut. i̇zlediği bir tiyatro oyunundan aklında kalanları o gece hiç vakit kaybetmeden ve etkisini yitirmeden resmetmek istiyor. Savaşın izlerini, mültecilerin yaşam mücadelelerini, canlı bombaların kana buladığı Ankara Garı'ndan yüreğini yakan anları, küçücük yaşta kaybettiği annesini ve kardeşlerini, çocuk parkında ağlayan torununu, okuduğu bir şiiri de resmediyor. Resimleri haftalarca aylarca sürmüyor, yaşanan olayın etkisi tazeyken, henüz canlıyken aktarmayı tercih ediyor. Sanatçı bu süreç uzarsa etkisini yitireceğini, duygularının şiddetinin değişeceğini biliyor. Bu nedenle süratle çalışıyor. Hızlı çalışmak ona şevki, coşkusu bazen de acısı, öfkesi tazeyken yansıtabilme imkanı sağlıyor. Resimlerindeki zengin dokular, hızlı ve anlık görüntüler, yoğun lekesel değerler, boya katmanları hep bu coşkunun dışavurumları olarak karşımıza çıkıyor. Pekmezci konuyla ilgili şunları dile getiriyor; "Resimlerimde içimden geldiği gibi betimlemeyi ilke edindim, sonradan düzeltmeler, makyajlamak gibi geliyor bana. Dahası duygusal tavrımın gerektirdiği anında oluşan rahatlığı hiç bozmak istemem. Bu çocuksu olabilir, deseni bozuk olabilir, anatomisi sakat olabilir. Benim "insan" diye betimlediğim insandan başka bir şey etkisi veriyorsa o zaman bozarım o resmi, sergilemem, bitirmem. "Insan" etkisi veriyorsa, benim akımdaki, beynimdeki konuyu ifade etmemi sağlıyorsa benim için yeterlidir. Aylarca bir resim üzerinde kesinlikle çalışmam. Duygularım, kaygım, heyecanım istim üzerindeyken, tavsamadan resmi bitirmek zorundayım. O duygudan uzaklaştı̆ı̆ımda resim mekanikleşir, renkler, biçimler, lekeler oyunu olur ama benim iç dünyamı temsil etmez. Ben renkler, biçimler, lekeler, kompozisyon oyunları ile resim yapmam. İçeriği; bir sözü, bir özü, olmayan, kof bir gösteridir benim için bunlar." Plahanov'un özlü bir sözü ile destekliyor anlattıklarını; "İçeriği olmayan resim ruhsuz, bir ceset gibidir". Ayrıca Pekmezci, sanatçının değişken ruh halinin eserine yansımasının doğallığını da vurguluyor; "Bugün huzurla resim yaparken betimlediğimiz konular, kullandığımız renkler, armoniler farklı bir yöne sürükler bizi. Ama kaotik bir günde o günün sancısına uygun bir konu, armoni, vücut tepkisi kendiliğinden oluşur. Bu okuduğumuz bir şiir olabilir, TV'den gördü̆g̈ümüz trajik bir olay da. Tanı̆̆ı olduğumuz bir uyaran da. Benim resimlerimde bu duyarlık her zaman vardı. 1970' te yaptığım bir resimde anamın tabutunu taşıyanları anlatmıştım; siyah-beyaz bir resim. 1980' lerde kardeş kavgalarını." (Görsel: 8,9,10)
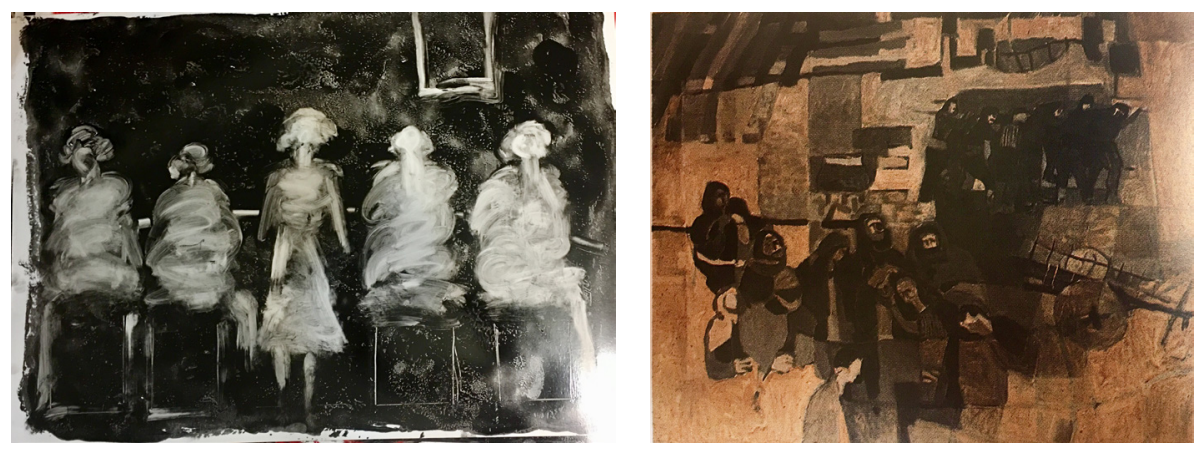

Görsel 8. Pekmezci'nin “Can Kırıkları" isimli tiyatro oyunu sonrası izlenimlerini resmettiği çalışması (Solda)

Görsel 9. Pekmezci'nin 1970'de yaptı̆̆ı, annesinin cenazesini anlattığı "Acı" isimli eseri. 


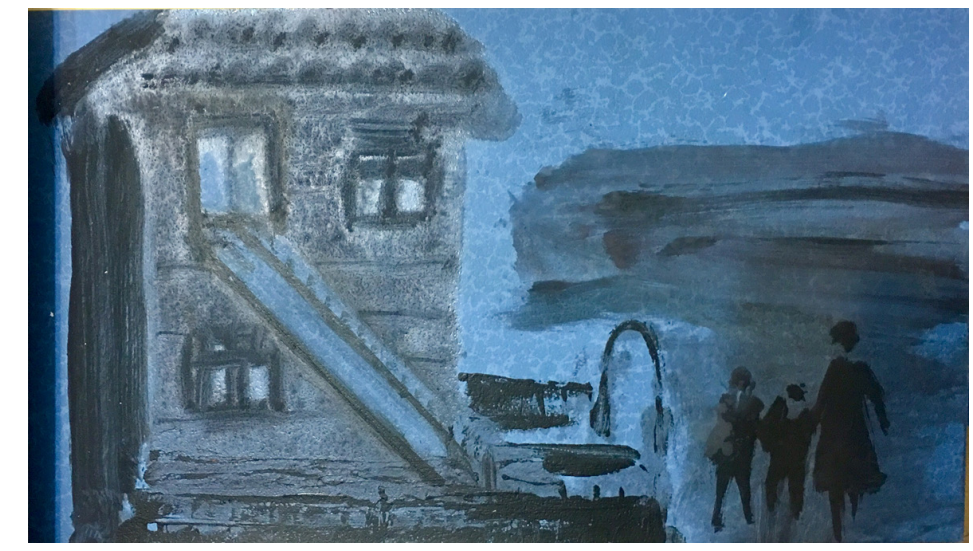

Görsel 10. Pekmezci'ye ait bir çocukluk anısını anlatan resmi.

Türkiye'de pek çok eğitim kurumunda Özgün Baskı Resim Atölyeleri kurmuş ve teknik ağırlıklı bir disiplinin inceliklerini öğretmiş bir sanatçı olarak Hasan Pekmezci, tekniğin sınırlandırıcılığına da karşı çıkmaktadır. Salt tekniğe bağımlılığın bir anlamda tutuculuk olduğunu tüm içtenliğiyle savunur. İnsanın sanatsal duyarlılığının ve yaratıcılığının her türlü teknik sınırlılıkların önüne geçebilecek güçte olduğunu vurgulamaktadır. Resim de yapar, siiir de yazar, öykü de yazar, resimli günlükler de tutar. Yeni bir şey öğrenmekten korkmaz, yeni bir şey denemekten çekinmez. Belli bir alanın, disiplinin, tekniğin ya da malzemenin arkasına sığınmaz. "Teknik sadece bir araç. Bu nedenle teknik tutuculuğuna inanmayanlardanım. İnsan yaratıcılığı sınırsızdır, her olanağı bir başka amaç için de, özgün baskı için de kullanabilir. Belki de çok daha ilginç yollar keşfine zemin için. Ben özgürlüğün sanatın vazgeçilmezi olduğunu savunuyorsam buna değin ne varsa onu da savunurum. Her insanın çoklu disiplinleri denemesi, uygulaması yanlısıyım, at gözlüğü ile "sadece kendi işimi yaparım" bana göre değil. Ayrıca "Bir koltuğa birden fazla karpuz sığmaz" diyen anlayışa da karşıyım. Bununla ilgili iki saat konferans verebilirim. Bu söz insana, onun yetilerine saygısızlıktır. İnceleyin, Rönesans insanı çok yönlü insandır. "Polimatmen" çok yönlü, çok bilgili, filozof-alim insan tipidir." Sözleri ile konuya duyduğu hassasiyeti dile getirmektedir.

Pekmezci'nin resimlerinde sıklıkla karşılaşılan bazı imgeler vardır. Kuşlar, kafesler, merdivenler, saatler, ağaçlar, pencereler, kalabalık insan grupları, kuş yuvaları gibi. Bunların arasından öne çıkan kuş ve kafesleri, merdiven ve saatleri kendisine sorduğumuzda çok derin hikayeler çıkıyor karşımıza. Pekmezci, resimlerinde sıklıkla ele aldığı kus ve kafes imgelerini 1970'lerin başından beri kullanmakta. Zaman zaman geri dönüşlerle betimlediği bu konuların tamamen kendi anılarından beslendiğini söylüyor. Çok eskilere gidip, köyde geçen hüzünlü çocukluk anılarında sevecen, anaç, koruyucu bir ana figürü bulunmakta. Derme çatma bir ahşap evde, onu sahiplenmiş, koruyan kollayan İrez Ana. Pekmezci henüz küçücükken ona doğa sevgisini, canlıların eşitliğini, yaşam haklarını öğretmiş sevgi dolu bir Anadolu kadını o. Hala sesinin kulaklarında çınladığı, hürmetle adını andığı̈ önemli bir kadın figürü. İşte Pekmezci'nin resimlerinde karşımıza çıkan o kuşlar ve kafesler bu kadar eskilere dayanmakta. Pekmezci resimlerindeki kuş kafesleri hakkında şunları söylüyor; "Kafeslerim aslında hep kırık döküktür, kuşlar için hapis yeri değildir; içine girip çıtıkları birer evdir, yuvadır. Kafes tamamen semboldür. Kuşlar dilerlerse benim betimlediğim kafesi bir ev-yuva olarak kullanabilirler." Pekmezci görkemli ağaçlar üzerinde kuş yuvalarını da sıklıkla kullanıyor. Uçan, konan, göçen hareketli kıpır kıpır kuşlar. Sanatçının geçmişiyle bağ kuran imgesel bir dil, günümüze yansıyan bir köprü. (Görsel: 11,12,13)
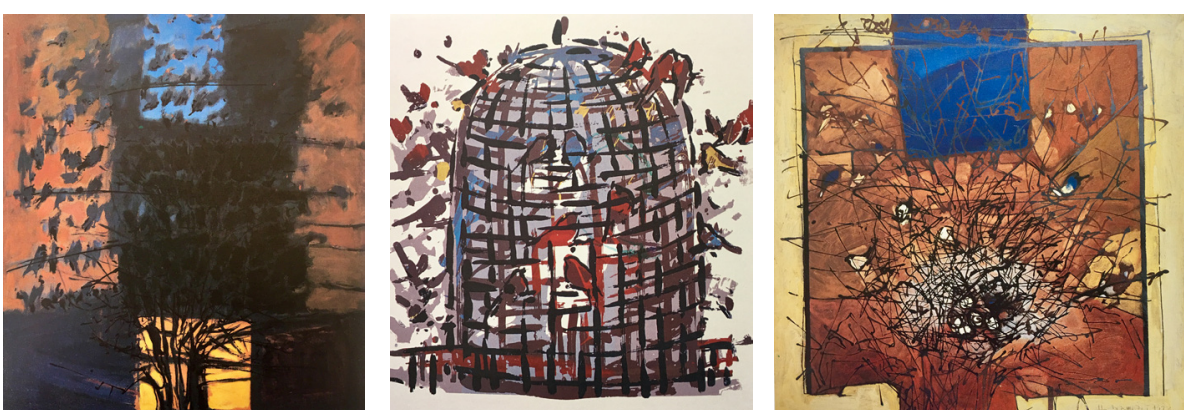

Görsel II. Hasan Pekmezci'ye ait "Kuşlar" isimli yağıboya resim, 199 I (Solda) Görsel I2. Hasan Pekmezci'ye ait "Kafes ve Kuşlar" isimli serigrafi resim, 1997 (Ortada) Görsel I3. Hasan Pekmezci'ye ait "Kuşlar" isimli yağıboya resim, 1993 (Sağda)

Kuşlar ve kafesleri gibi Pekmezci'nin resimlerinde gördüğümüz merdivenleri de sanatçının hayatında yer alan önemli anılardan yansımaktadır. Bir insanın zorluklarve mücadeleiçinde tırmandığıyaşam merdivenin öyküsüdürözetle. Hedeflerine ulaşmak için, hayata tutunmak için, ulaştığı yerde kalabilmek için emekle, çabayla basamakları tek tek tırmanmasının öyküsüdür. Çocukluğunda köydeki bakkalın duvarında gördüğg̈ bir resimden evrilerek sanatçının eserlerinde vazgeçilmez bir konu olmuş olan bu merdivenlerin hikayesini kendisinin şu sözleriyle öğrenmekteyiz " Öyküsü eski olmakla birlikte ellinci yaș dönemimde başladı, "Yaşam Merdivenleri" resimlerim. Bir merdivenin tepesine anlatılması güç mücadelelerle çıkabilmiş bir insan olarak, ta çocukluğumdaki Amed Emminin dükkanındaki merdivenin betimlediği gibi: Abalamışım, çabalamıştım merdivene tırmanmak için. 
Devlet babanın elinde İvriz gibi bir ülkü ve ideal ocağında bilgi-bilinçkimlik. Sonra yokluk içinde, İstanbul'da, Çapa'da ilk gençlik yılları. Sonra eşim olmuştu yanımda; sonra çocuklarım, tepeye çıktıkça başarılarımız, adımız-sanımız... En tepeye yani ellinci basamağa çıktığım yıl büyük kızımız uçmuştu yuvamızdan. "Dank etmiş̧i"' beynimize yaşamın bir başka gerçeği. Merdivenden iniş başlamıştı, yaşamla birlikte geri sayım, bir yandan da. Çok geçmedi, ikinci kızımız da uçup gidiverdiğinde "Hanya'yı-Konya'yı" anlamaya başlamıştık eşimle. "Edi-büdü" iki can kalıvermiştik evimizde. Daha bilinçli-daha duygusal, daha acımasız öz eleştiri ve sorgulamalarla. Geride kalan yılların birikimi, ağır yükü, iniş açısının eğimi; iniş hızını bilinmezlere-menzile doğru alabildiğine artıran. Nasıl elli, altmış, yetmiş oluverdi dedirten. Sahi ne zaman 72 yaşına geliverdik?... Her merdiven resmim bireysel olarak benim, eşimin, ailemin; geride kalan her basamağı emekle, onurla tırmandığımız yaşam mücadelemizin betimlemesi, izi, belgesi, kanıtı. Bunların her biri sanatı, yaşamın bütün gözlemlerinin, anılarının, duyarlıklarının, sesli-sessiz, renkli-renksiz anlatımı, paylaşımı, deşifresi olarak gören biri için gece gündüz, dur durak bilmeden çalışma, sergiler dolusu resim yapma-yaptırma nedeni olamaz mı?" Pekmezci için resimlerinde kullandığı merdivenler yaşamın sorgulanması anlamını taşımakta. Özellikle altın yaldız ile vurguluyor merdivenlerini daha da pekiştirmek için "Yaldızıdır merdivenlerim. Her adımı, her basamağı altın. Anlamını değerini vurgulamak için. Bu duygularımı Ahmet Haşim'in "Merdiven" şiiri daha çok tetikledi diyebilirim.

“Ağır ağır çıkacaksın bu merdivenlerden,

Eteklerinde güneş rengi bir yığın yaprak

Ve bir gün bakacaksın semaya ağlayarak"

Elli yaşımdan sonra yani inişe geçtikten sonra daha çok sevdim bu merdiven resimlerimi. Yaşamla sanatın birlikteliği; duyumsama ile betimleme..." (Görsel: 14,15,16)
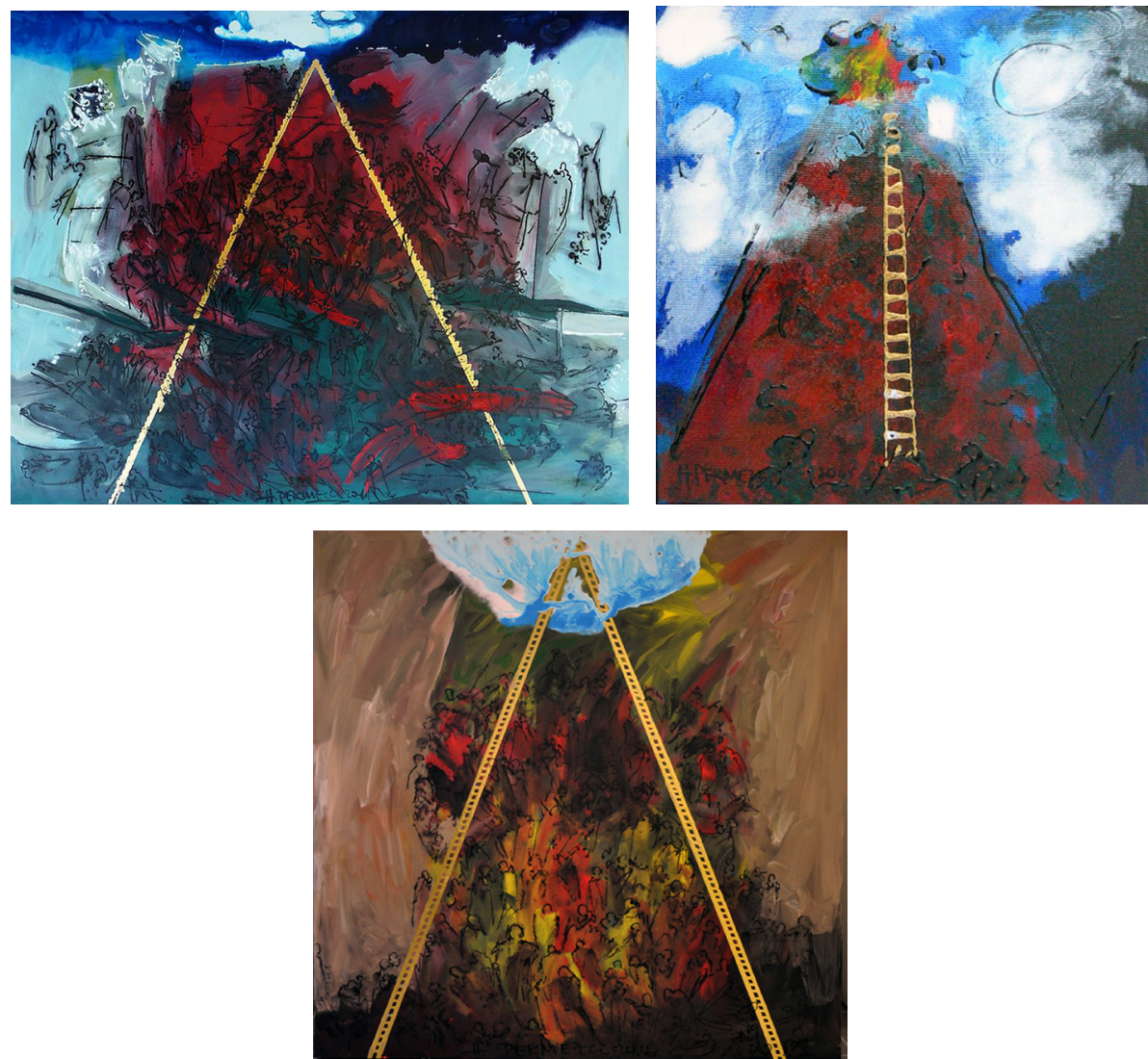

Görsel 14. Hasan Pekmezci'ye ait "Yaşam Merdiveni" isimli tuval üzerine akrilik resim, 2011 (Sol Üstte)

Görsel 15. Hasan Pekmezci'ye ait "Yaşam" isimli yağlıboya resim, 2005 (Sağ Üstte) Görsel I6. Hasan Pekmezci'ye ait "Yaşam" isimli karışık teknik resim, 2010 (Altta)

Hasan Pekmezci'nin son dönemlerde resimlerinde sıklıkla karşılaştığımız saat imgesi bize sanatçının zaman kavramını sorguladığı bir dönemin sanatsal yansımalarını hissettiriyor. "Akıp Giden Zamana Ağıt" isimli yazısının başında kaleme aldığı etkileyici şiiri konuyu özetliyor sanki;

"Kolundaki altın kol saati değildir değerli olan, onun tik takları içinde akıp giden saniyelerdir.

Kolundaki altın kol saatinin markasıyla, fiyatıyla değil; onun gösterdiği her saniyenin altın değerinde olduğunu anladığın zaman öğünmelisin. 
Her şeye bir bedel biçilebilir; ancak, geri getirilemeyecek, durdurulamayacak, değer biçilemeyecek tek şey zamandır.

Ey insanoğlu, dünyanın servetine de sahip olsan, bir saniyelik zamanı bile satın alamayacak kadar fakir ve çaresizsin.

Bir insanı kırmak için bir saniye yeterlidir, ancak onu kazanmak için ömrünüz yetmeyebilir.

Sizi kimlik haline getiren, maddi servetiniz, yaşadığınız uzun yıllar değil, bu yaşamın içini iz bırakan eserlerle doldurup, doldurmadığınız; hakkını verip vermediğinizdir."

Sanatçı, zamanın değerini ve insanın zaman algısının asında nasıl da yanııtıcı olduğuna değiniyor ve resimlerindeki saatleri şu sözlerle anlatıyor; "Saat, zaman yaşımızla birlikte daha da anlam kazanan semboller, kavramlar. Çok hızla akıp giden, asla geri dönmeyen, milyonlar verilse dakikasını geri alamayacağımız muazzam bir değer. Bu durum belli yaşlarda farkına varılmayan ama farkına varıldığında da insanın bütün benliğini saran bir duygu. Bir zamanlar "Ooo daha çoook zaman var" derken, bir zaman geliyor; geride kalan zamanın ne kadar azaldığı kaygısı, saatlerin akrep ve yelkovanlarının çok daha hızla döndüğü bir duygu dünyası başıyor. Hatta panik yaşatıveriyor insana. Bu nedenle saat/zaman kavramı benim çok önem verdiğim bir konu ve bütün duygularımı, yaşamımı, yaşama bakışımı temsil ettiğine inandığım resimlerim." (Görsel:17,18,19)
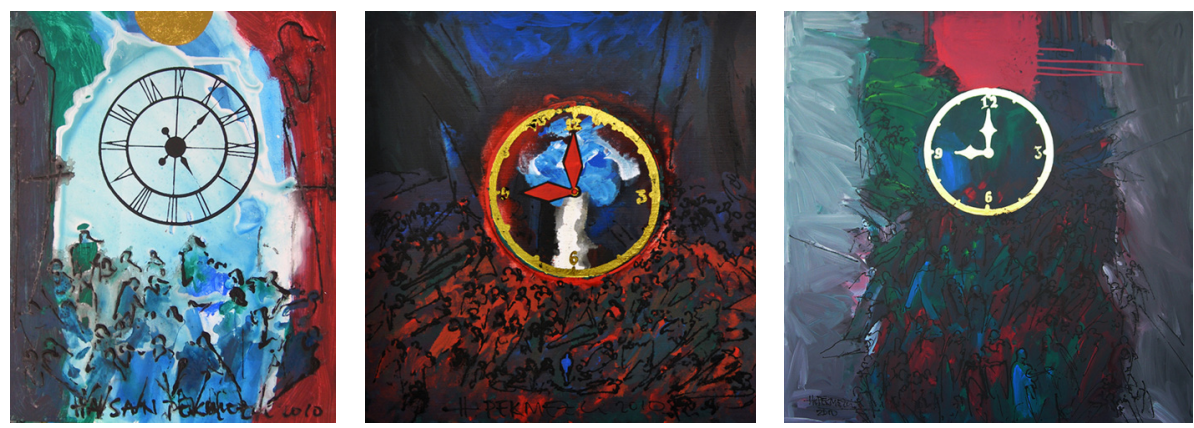

Görsel I7-I8-19. Hasan Pekmezci'ye ait "Zaman” isimli karışık teknik resimler, 2010.
Sanatın bir bütün olduğunu devamlı vurgulayan Hasan Pekmezci, hayatını resmin yanısıra başka sanatsal üretimlerle de zenginleştiren bir sanatçıdır. Öyküler yazar, çoğu kişinin bilmediği 200'e yakın şiiri vardır, çocuk resimleri inceler, resimli günlükler tutar, sanat eğitimci yanını sosyal sorumluluk projeleri ile birleştirir, çok okur, iyi bir koleksiyoncudur. Buradan donanımlı bir sanatçının çok yönlü üretimler içerisinde olmasının önemini de çıkarabilmekteyiz.

Değerli bir eğitmen, üretken bir akademisyen ve ülkemizin yetiştirdiği en değerli sanat insanlarından Hasan Pekmezci için başarının anlamın soruyorum. "Başarı çok sübjektif bir kavram ama temelinde tutku ile çalışma var. Mustafa Ayaz 'Ben yetenekli falan değilim, benim kadar çalışan herkes mutlaka güzel şeyler yapar' der. Michaelangelo' nun 'Bulunduğum noktanın yüzde doksan dokuzu calışma; yüzde biri yetenek' der. Sanat bir felsefe gerektirir. Buna yaşam felsefesi temel dayanaktır. Yaşam felsefesi olmayanın sanat felsefesi de olmaz. Çünkü felsefe sorgulamadır. Neden yaşıyoruz, niçin, nasıl sorgulamalarıyla anlam yükler yaşama. Neden?, niçin?, nasıl sanat? sorularına yanıt arayan, sorgulayan, kendini sorgulatandır, sanat. Yaptıklarını sorgulamayan, kendini yargılamayan sanatçı olamaz. Ressam olur, seramikçi olur, heykelci olur, ama sanat sorgulamayla başlar. Bu nedenle sanat felsefesi kesinlikle sanat eğitiminin temel dayanağı olmalıdır, bütün eğitim kurumlarında. Tarih incelendiğinde batan imparatorlukların, devletlerin yıkılış nedenlerinin başında eğitim kurumlarından felsefe, mantık, bilim, fenin kaldırılması gelir. Toplumu düşünmez, tabi olur, ümmet olur, kül köle yapmak isteyenlerin ilk işi bu alanları ortadan kaldırmak, dejenere etmektir. Çok çalışma, çok araştırma. Çok okuma, mutlaka yazma. Ama içtenlik, özgünlük, özgürlük. Fark yaratma. Benim olsun, beni temsil etsin ama kötü olsun, diyenlerdenim. Bana 'filancanın tekrarcısı' diyeceklerine çok kötü, berbat bir ressam desinler daha iyi. Başkalarının yaşamını anlatmak yerine insanın kendi yaşamını anlatması temel ilke olmalıdır. Başkalarının rolüne soyunmak, başkalarının kimliğine bürünmek demektir. Ben kendi kimliğim varken niye başkasına yamanayım ki. Başarıda özellikle sanat gibi çok hassas, kırılgan, duygusal yönü baskın alanlarda inatla, sabırla, mücadele içinde olma zorunluluğu var. İnsanın kendi kendisi ile yarışması, kendini her resimde aşma çabası. Bu nedenle 1958 yılından beri resmin içindeyim. Hiç ara vermediğimi kesinlikle söyleyebilirim. İlk resmim 1968'de satıldı. İki resim parası ile aldığım ilk şey Amerikan Neşriyat Bürosu kanalıyla ABD'den sanat kitapları getirtmek oldu. Türkiye'de sanat kitabı bulmak ne zordu o zamanlar. Ben başarılı sayanlardan değilim kendimi. Çok çalışan olarak bilinmeme rağmen, neredeyse 24 saatimi tam kullanma çabasında olmama rağmen. Randımanı düşük bir işletme gibi hissederim hep. tek olumlu yanım 
alı̧̧kanlıklarım, elim boş durmamalı, çizmeli, karalamalı, oynamalı. Yazılı günlük tutarım yıllardır. Yazma eylemini çizme eyleminden ayrı düşünmem. Her gün mutlaka bir makale üzerinde çalışııım. Yarına yetişecekmiş gibi. yarın dersim varmış gibi araştırma yaparım. Bir alıntının kaynağıı bulmak için sabahladığım çok olur, inatlaştığımdan. Şu an benden yirmi konferans isteseler hepsi hazır. 20 makale isteseler, hazır. Sergilemek için 500 resim isteseler hazır. yayınlamak isteseler 200 şiir, bir o kadar öykü-anı hazır. Buna rağmen daha sistemli çalışabiliir, daha randımanlı üretebilirdim, diye düşünürüm öz eleştiri olarak."

Bu değerli söyleşinin sonuna doğru gelirken Hasan Pekmezci Hoca'ma üzerindeçalıştığı en son projelerinisoruyorum. Sürükleyicibir kitaptadındaki bu keyifli sohbetimiz için teşekkürlerimi sunarken sanat öğrencilerine, genç akademisyenlere, sanatçוlara ne gibi tavsiyeleri olabileceği sorusunu yöneltiyorum. "On-yirmi yıllardır bir projem var, uykularımı kaçıran, bir türlü hayata geçiremediğim; $200 \times 300 \mathrm{~cm}$. boyutlarda 50 resimlik bir seri. Böyle resimleri çalışabilmek için büyük bir mekan bulmak çok zor. Bizde bazı konuları 'Sadece biz biliriz, biz yaparı' takıntıları var. Ben 'Bir insan eğer isterse her seyi yapabilir, ama kendisi kadar. Herkes resim yapabilir, ama kendisi kadar-Picasso gibi değil. Herkes seramik yapabilir ama Füreya gibi Atilla Galatalı gibi değil, kendisi kadar. Yaşayabildiğim sürece eğitimciliğim, sanat alanım yaşama bağlılığım demektir. Yaşam herkes için 'Bir varmış bir yokmuş' oyunudur. Bu geride bırakılabilen eserlerle belki biraz daha uzayabilir ancak. Bu nedenle bizi sanata, iz bırakmaya yönlendiren her an sevgi ve saygı ile andığım bütün öğretmenlerimize minnet duygularımı sunuyorum. Biz birşeyler yapabilmisssek sadece onların sayesindedir, bunun bilincindeyim. Bütün gençlerimiz iyiyi, güzeli, doğruyu, çağdaşlığı hak eden pırlantalarımızdır. Hepiniz umudumuzsunuz. Mutluluğunuz, başarılarınız sonsuz olsun."

\section{Kaynakça*}

* Bu yayının temel kaynağııı makalenin yazarı Deniz Onur Erman tarafından 06.05.2018 ve 08.05.20I 8 tarihlerinde Prof. Hasan Pekmezci ile yapılmış olan sözlü ve yazılı röportajlar oluşturmaktadır.

Pekmezci, H. "Eşi Insanın Nefesidir" (http://www.hasanpekmezci.com/esi-insaninnefesidir/)

Pekmezci H. "Sanat alanı ister iki, ister üç boyutlu olsun, sanatçının mahremiyetidir." https:// www.kultursanatharitasi.com/sanat-alani-ister-iki-ister-uc-boyutlu-olsun-sanatcininmahremiyetidir/

Pekmezci, H. "Yaşamın Anlamı ve Yaşamak"( http://www.hasanpekmezci.com/yasaminanlami-ve-yasamak/)

Pekmezci, H. "Yaşam Dedikleri / Eni Boyu Kavgadır" http://www.hasanpekmezci.com/ yasam-dedikleri-eni-boyu-kavgadir

Pekmezci, H. "2I. Yüzyıla Doğru Türkiye'de Sanat" http://www.hasanpekmezci.com/2 Iyuzyila-dogru-turkiyede-sanat/

Pekmezci, H. "Yaşam Kısa, Sanat Sonsuz" http://www.hasanpekmezci.com/yasam-kisasanat-sonsuzl

http://ekitap.kulturturizm.gov.tr/TR,80267/vi-1980-sonrasi-sanat-gelismeleri.html

\section{Görsel Kaynaklar}

I,2,3,4- Kişisel fotoğraf arşivi

5- (https://www.brhd.org.tr/hasan-pekmezci-278) (erişim: 10.05.2018)

6-7- (http://www.hasanpekmezci.com/calismalari) (erișim: 10.05.2018)

8-9- Kişisel fotoğraf arşivi

10-I I-I3- 03-26 Şubat 1994 Ankara, Emlak Sanat Galerisi sergi kataloğu.

12- 24 Ekim- 25 Kasım 2000, Ankara, IMKB Sanat Galerisi sergi kataloğu.

14- (https://wikimedia.org/Hasan_Pekmezci.jpg. (erişim: II.05.20/8)

15-I6-I7-I8-19 http://www.artsnt.com/hasan pekmezci.php (erişim II.05.20/8) 